\title{
Induction of Humoral and Cell-mediated Anti-Human Immunodeficiency Virus (HIV) Responses in HIV Sero-negative Volunteers by Immunization with Recombinant gp160
}

\author{
Joseph A. Kovacs, * M. B. Vasudevachari, ${ }^{*}$ Margaret Easter, ${ }^{3}$ Richard T. Davey, Judith Falloon, * \\ Michael A. Polis, " Julia A. Metcalf," Norman Salzman," Michael Baseler," Gale E. Smith," \\ Franklin Volvovitz," Henry Masur, " and H. Clifford Lane" \\ ${ }^{*}$ Critical Care Medicine Department, Clinical Center, National Institutes of Health, Bethesda, Maryland 20892; ${ }^{\ddagger}$ Laboratory of \\ Molecular Retrovirology, Department of Microbiology, Georgetown University, Washington, DC 20007; ${ }^{8}$ Clinical and Molecular \\ Retrovirology Section, Laboratory of Immunoregulation, National Institute of Allergy and Infectious Diseases, National Institutes \\ of Health, Bethesda, Maryland 20892; "Program Resources Inc., Frederick, Maryland 21702; \\ and 'MicroGeneSys Inc., Meriden, Connecticut 06450
}

\begin{abstract}
Development of an effective vaccine for prevention of infection with HIV would provide an important mechanism for controlling the AIDS epidemic. In the current study, the first clinical trial of a candidate HIV-1 vaccine initiated in the United States, the safety and immunogenicity of escalating doses (10$1,280 \mu \mathrm{g})$ of recombinant gp160 (rgp160), were evaluated in $138 \mathrm{HIV}$-negative volunteers. Maximal antibody responses, as evaluated by ELISA, were seen after immunization with three doses of $1,280 \mu \mathrm{g}$ rgp160. Responses to some specific epitopes of HIV gp160, including the second conserved domain and the CD4 binding site, were seen more frequently than after natural infection. Neutralizing antibodies to the homologous HIV strain, but not heterologous strains, were induced by this regimen. Blastogenic responses to rgp160 were seen in most volunteers receiving at least two doses of $\geq 20 \mu \mathrm{g}$. These envelopespecific $T$ cell responses were also seen against heterologous strains of HIV. No major adverse reactions were seen after immunization. Thus, rgp160 is a safe and immunogenic candidate HIV vaccine; further studies are needed to determine if it will provide any clinical benefit in preventing HIV infection. $(J$. Clin. Invest. 1993. 92:919-928.) Key words: AIDS • retrovirus - safety • immunogenicity • vaccine
\end{abstract}

\section{Introduction}

Development of an effective HIV vaccine is a critical goal of the effort to control the AIDS epidemic (1-5). Although a number of antiretroviral agents that are potentially effective in delaying disease progression in HIV-infected patients, such as zidovudine, have been identified, no agent has yet been identified that will effectively prevent progressive immunodeficiency and its devastating consequences (6-11). Prevention of infection or modification of the clinical course of HIV-induced disease is thus crucial to stemming the AIDS epidemic.

Address correspondence to Joseph A. Kovacs, Building 10, Room 7D43, National Institutes of Health, Bethesda, MD 20892.

Received for publication 3 August 1992 and in revised form 31 March 1993.

The Journal of Clinical Investigation, Inc.

Volume 92, August 1993, 919-928
Developing a vaccine for HIV poses a number of problems $(1,5)$. Numerous studies have demonstrated the presence of specific, potentially protective activities of the immune system, such as neutralizing antibodies (12-18), cell-mediated cytotoxicity (19-23), and antibody-dependent cellular cytotoxicity (18, 24-29), in individuals with HIV infection, but no study to date has convincingly demonstrated which specific immune mechanisms, if any, will protect against HIV infection or HIVinduced immunosuppression in humans. Moreover, the presence of a hypervariable region in the principal neutralizing domain as well as in other regions of the HIV outer envelope protein, gp120, has raised concerns that HIV will be able to evade the effects of neutralizing antibodies through changes in these regions (13-17, 30, 31).

Although the challenge of developing an effective AIDS vaccine is formidable, recent studies using simian immunodeficiency virus (SIV) ${ }^{1}$ infection in monkeys have demonstrated protection against challenge with SIV after immunization with whole, inactivated SIV (32-34) or a live, attenuated SIV (35). Further, evaluation of SIV subunit vaccines has suggested that glycoprotein-enriched fractions, which include the envelope proteins, are responsible for the observed protection (36). Although recent reports have suggested that protection in studies using whole inactivated SIV resulted from development of antibodies to cellular components (37-41), in a recent study, complete protection was conferred after immunization with recombinant vaccinia virus-expressed envelope protein followed by immunization with baculovirus-expressed protein (42). Studies in chimpanzees have also demonstrated partial protection against HIV infection after variable immunization schemes and immunogens, including immunization with recombinant gp120 (43) as well as combinations of whole inactivated virus, recombinant, vaccinia virus-derived, gp160, and keyhole limpet hemocyanin (KLH)-conjugated peptides corresponding to the V3 loop of gp120 (44). More recently, protection of chimpanzees against challenge with cell-associated virus has been reported (45). These studies clearly demonstrate that, in an animal model of HIV infection or of a disease closely related to AIDS, protective immunity can be induced by immunization and thus support the concept that protective immunity against HIV can be induced in humans. Further, a recent study using a mAb to the V3 loop of $\mathrm{HIV}_{\mathrm{III}}$ demonstrated that infec-

1. Abbreviations used in this paper: $\mathrm{KLH}$, keyhole limpet hemocyanin; NIAID, National Institute of Allergy and Infectious Diseases; rgp 160, recombinant gp160; SIV, simian immunodeficiency virus. 
tion by HIV $_{\text {IIIb }}$ could be prevented by administration of this antibody before or immediately after intravenous challenge, suggesting that antibodies alone may be sufficient to prevent spread of cell-free virus (46).

Given the urgency of the problem, in 1987 we initiated the first HIV vaccine trial in the United States, using a baculovirusexpressed recombinant gpl60 (rgp 160) adsorbed to alum as the immunogen $(47,48)$. The goals of the study were to evaluate the safety of immunizing humans with the envelope of HIV; to evaluate the nature of the immune response that could be elicited with a recombinant HIV envelope protein; and to establish a dose-response relationship between immunogen and level of immune response. In this study, we have demonstrated that high doses of rgp 160 can be safely administered to seronegative volunteers, and that rgp 160 will induce neutralizing antibodies in a dose-dependent manner.

\section{Methods}

Immunogen. rgp 160 was generated by cloning the env gene of LAV-1, obtained from an infectious HIV clone, into an expression vector derived from the baculovirus Autographa californica Nuclear Polyhedrosis Virus (47). Recombinant protein was produced in Lepidopteran cell cultures, purified, and adsorbed to alum (VaxSyn HIV-1; MicroGeneSys Inc., Meriden, CT) (47). rgp160 has a molecular weight of $\sim 160,000$, is glycosylated, and exists in its purified form as a tetramer. Initial rgp 160 preparations, used in the 10-80 $\mu$ g per dose immunizations, were $>80 \%$ pure, as estimated by densitometry of SDS-PAGE gels. Subsequent lots were $>95 \%$ pure. The final formulation contained $10-640 \mu \mathrm{grgp} 160 / \mathrm{ml}$ of vaccine.

Immunization. The study was conducted in two parts. In the first part, healthy homosexual or bisexual men between the ages of 18 and 60 with no evidence of HIV infection or existing medical problems were sequentially enrolled in eight groups of 15 patients. All volunteers received an initial immunization of $10,20,40,80,160,320,640$, or $1,280 \mu \mathrm{g} \mathrm{rgp} 160.10$ volunteers in each group received a booster immunization at $1 \mathrm{mo}$; five received one half the original immunizing dose, and 5 received the full immunizing dose. Three additional volunteers received $80 \mu \mathrm{g}$ followed by a full-strength boost when a new vaccine lot was used. A subgroup of volunteers receiving $\geq 160 \mu \mathrm{g}$ who had received a 1-mo boost were eligible for additional full-strength booster immunizations at 6, 12-18, and 18-24 mo.

In the second part, designed to examine the specificity of the response, volunteers were randomized in a double-blind fashion to immunization with either rgpl60 or $\mathrm{KLH}$, each at a dose of $320 \mu \mathrm{g}$. Fullstrength booster immunizations were administered at 1 and 6 mo. 10 homosexual or bisexual men and 5 heterosexual men participated in this phase.

All immunizations were administered into the deltoid muscle. Volunteers were seen in clinic weekly for $1 \mathrm{mo}$ after the initial immunization and then monthly. At each visit, a brief history, including possible reactions to immunization, was elicited and blood was obtained for evaluation of safety and immune responses.

Laboratory assays. To detect antibody responses to specific HIV proteins, sera ( $1: 100$ ) were evaluated using a commercial immunoblot kit (DuPont Co., Wilmington, DE). Reactivity with individual bands was scored as positive if any reactivity with that band was visualized. Antibody responses were quantitated by ELISA, using a commercial kit (Abbott Laboratories, Abbott Park, IL). ELISA results were compared with a standard curve generated using a control serum from an HIV-infected patient and are expressed as units, with $1 \mathrm{U}$ being defined as the amount of antibody present in a 1:2,100,000 dilution of the control serum.

Antibody responses to specific epitopes were determined by immunoblot, using purified Escherichia coli malE-gp160 epitope fusion proteins as previously described (48), for antibodies to the following epi- topes: gp 120 constant region 1 (49-128), constant region 2 (254-274) (12), constant region 3 (342-405), the CD4 binding domain (422$454)(49,50)$, the $\mathrm{COOH}$ terminus of $\mathrm{gp} 120(453-518)(51)$, hypervariable region $3(\mathrm{~V} 3 ; 300-340)(14,16)$, the immunodominant domain of gp41 (579-605) (52), and a putative neutralizing region in gp41 (735-752) (53). The epitope blots were incubated with a 1:1,000 dilution of primary serum overnight at room temperature, washed, and incubated for $1 \mathrm{~h}$ at room temperature with alkaline phosphatase-conjugated goat anti-human IgG. Epitope responses were quantitated by ELISA, using serial twofold dilutions of sera, starting at 1:50. Plates were coated with purified epitope fusion proteins or rgp160 at $100 \mathrm{ng}$ per well. The end point titer was defined as the titer that gave an OD $\geq 0.05$, which was also at least fourfold higher than the mean OD of pooled normal human serum.

Neutralization was determined using an MT2 cell assay (54). Briefly, twofold dilutions of serum samples were incubated in triplicate at $37^{\circ} \mathrm{C}$ for $90 \mathrm{~min}$ with a stock culture of the indicated HIV isolate; this mixture was then incubated at $37^{\circ} \mathrm{C}$ with MT2 cells for $1 \mathrm{~h}$, the cells were washed twice, and then were incubated at $37^{\circ} \mathrm{C}$ for $3 \mathrm{~d}$, at which time supernatant p24 antigen was determined by an antigencapture ELISA kit (Abbott Laboratories). Neutralization was defined as a $50 \%$ decrease in p24 antigen when comparing results with immune serum to preimmune serum. Cell fusion inhibition assays for select samples (diluted 1:10) were performed by a National Institute of Al-

Table I. Proportion of Volunteers Who Developed Antibodies to HIV Proteins as Assessed by Immunoblotting After Immunization with rgp160

\begin{tabular}{cllll}
\hline Dose/boost & gp160 & gp120 & gp41 & p88 \\
\hline 160 $\mu \mathrm{g}$ & & & & \\
Primary & $0 / 15$ & $0 / 15$ & $0 / 15$ & $0 / 15$ \\
Boost 1 & $0 / 10$ & $0 / 10$ & $0 / 10$ & $0 / 10$ \\
Boost 2 & $4 / 5$ & $4 / 5$ & $0 / 5$ & $1 / 5$ \\
Boost 3 & $4 / 4$ & $4 / 4$ & $3 / 4$ & $4 / 4$ \\
Boost 4 & $4 / 4$ & $4 / 4$ & $3 / 4$ & $3 / 4$ \\
320 $\mu \mathrm{g}$ & & & & \\
Primary & $0 / 15$ & $0 / 15$ & $0 / 15$ & $0 / 15$ \\
Boost 1 & $0 / 10$ & $0 / 10$ & $0 / 10$ & $0 / 10$ \\
Boost 2 & $6 / 6$ & $5 / 6$ & $3 / 6$ & $4 / 6$ \\
Boost 3 & $5 / 5$ & $5 / 5$ & $5 / 5$ & $5 / 5$ \\
Boost 4 & $5 / 5$ & $5 / 5$ & $5 / 5$ & $5 / 5$ \\
$640 \mu \mathrm{g}$ & & & & \\
Primary & $0 / 15$ & $0 / 15$ & $0 / 15$ & $0 / 15$ \\
Boost 1 & $5 / 10$ & $5 / 10$ & $0 / 10$ & $0 / 10$ \\
Boost 2 & $6 / 6$ & $6 / 6$ & $5 / 6$ & $5 / 6$ \\
Boost 3 & $5 / 5$ & $5 / 5$ & $5 / 5$ & $5 / 5$ \\
Boost 4 & $3 / 3$ & $3 / 3$ & $3 / 3$ & $3 / 3$ \\
$1,280 \mu \mathrm{g}$ & & & & \\
Primary & $3 / 15$ & $3 / 15$ & $0 / 15$ & $0 / 15$ \\
Boost 1 & $7 / 10$ & $7 / 10$ & $0 / 10$ & $1 / 10$ \\
Boost 2 & $6 / 6$ & $6 / 6$ & $4 / 6$ & $6 / 6$ \\
Boost 3 & $6 / 6$ & $6 / 6$ & $6 / 6$ & $6 / 6$ \\
Boost 4 & $6 / 6$ & $6 / 6$ & $6 / 6$ & $6 / 6$ \\
\hline
\end{tabular}

Responses to individual HIV proteins after immunization with rgp 160, as assessed by immunoblotting. Sera were obtained weekly for $4 \mathrm{wk}$ after the initial immunization, and then monthly. Results are presented for the $160-\mu \mathrm{g}$ and higher groups. No reactivity by immunoblot was seen after immunization with up to two doses of 80 $\mu \mathrm{g} \mathrm{rgp} 160$. Results obtained after immunization at boost 1 with 50 or $100 \%$ of the original dose have been combined because no differences were seen in these groups. 
lergy and Infectious Diseases (NIAID) central immunology laboratory (Dr. Thomas Matthews, Duke University, Durham, NC) with the HIV $_{\text {IIb }}$ isolate using previously published methods (55).

For blastogenic assays, peripheral blood mononuclear cells were obtained by Ficoll-Hypaque density gradient centrifugation and either assayed immediately or cryopreserved to allow simultaneous assay of sequential samples from the same volunteer. Proliferative responses to rgp160 (MicroGeneSys, Inc.) at concentrations of 10,5 , or $1 \mu \mathrm{g} / \mathrm{ml}$ were determined in microtiter plates in triplicate using standard techniques (56). During the early part of the study, blastogenic responses to baculovirus proteins alone served as a control for responses to contaminating proteins. After demonstrating a lack of response to baculovirus proteins, subsequent assays used serum controls. Recombinant envelope proteins from $\mathrm{HIV}_{\mathrm{NY}-5}(57)$ and $\operatorname{SIV}_{\text {mac251 }}$ (33) were expressed and purified to $>95 \%$ using the same procedures as for rgpl60 vaccine. Cultures were incubated for $5 \mathrm{~d}$ and proliferative responses were measured by incorporation of $\left[{ }^{3} \mathrm{H}\right]$ thymidine. For presentation of data, background counts were subtracted, and results are presented as mean cpm.

CD4 and CD8 counts were determined by FACS analysis using standard techniques (56).

The protocol was approved by the institutional review board of the NIAID and all volunteers provided written informed consent after the risks of the study had been explained.

\section{Results}

A total of 138 volunteers, aged 19-58 (mean $36 \mathrm{yr}$ ) were enrolled in the study. 23 volunteers in the $160-1,280-\mu$ groups received three or more immunizations. Antibody responses by immunoblot were initially detected in the group receiving three immunizations with $160 \mu \mathrm{g}$ (Table I and Fig. 1). Maximal antibody responses were seen after three immunizations with $1,280 \mu \mathrm{g}$. In this latter group, antibodies were detected after a primary immunization. Reactivity by immunoblot was initially to gp160 and gp120. Antibodies to gp41 were seen only after the second booster immunization, even in the $1,280-\mu \mathrm{g}$ group. In addition, reactivity was also seen with a band with a molecular weight $\sim 88,000$ (Fig. 1), a previously uncharacterized band also seen on immunoblots when using serum from patients infected with HIV-1, which thus is presumably an envelope-related protein.

Quantitation of antibody responses by ELISA for the 18 patients in the 160-1,280- $\mu$ g groups who received five immunizations are summarized in Fig. $2 a$. Near maximal responses were seen in the 640 - and $1,280-\mu \mathrm{g}$ groups after three immunizations; similar responses were seen in the 160 - and $320-\mu \mathrm{g}$ groups after four immunizations. Although titers fell between immunizations, there was a rapid anamnestic response after rechallenge. In six patients in the 640 - and $1,280-\mu \mathrm{g}$ group, antibody responses after the fifth immunization were measured more frequently; peak responses were seen within 2 wk in most patients and declined to $50 \%$ maximal levels by $8 \mathrm{wk}$ after immunization (Fig. $2 b$ ).

To identify specific epitopes against which antibodies were induced, immunoblot studies using recombinant fusion proteins containing functionally important epitopes of gp 160 were performed after four immunizations (Table II and Fig. 3). The region of gp4 1 (579-605) that is immunodominant after natural infection was also a dominant epitope of rgp 160, with $100 \%$ of the volunteers who produced epitope antibodies responding to this region. However, immunization also resulted in humoral responses to some HIV gp160 epitopes that were only infrequently recognized by sera from HIV-infected patients. No antibody responses were seen when the V3 loop sequences from $\mathrm{HIV}_{\mathrm{MN}}, \mathrm{HIV}_{\mathrm{Z84}}$, and $\mathrm{HIV}_{\mathrm{RF}}$ were used in the immunoblot assays.

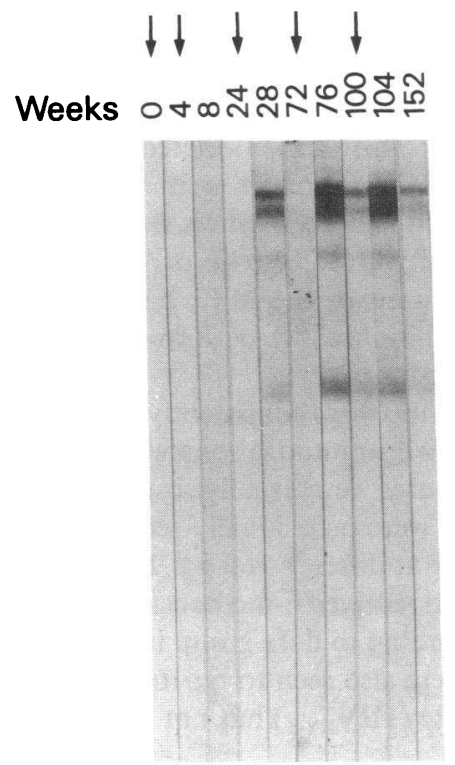

$160 \mu \mathrm{g}$
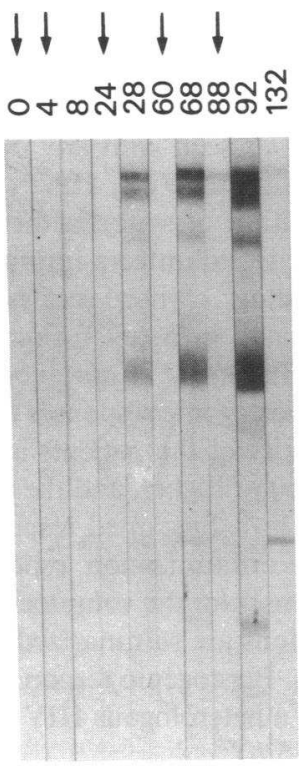

$320 \mu \mathrm{g}$
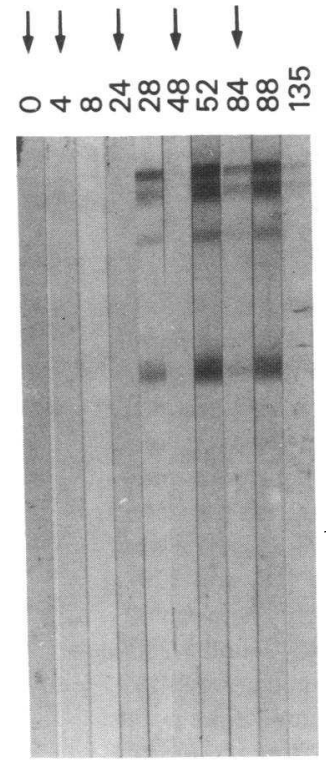

$640 \mu \mathrm{g}$
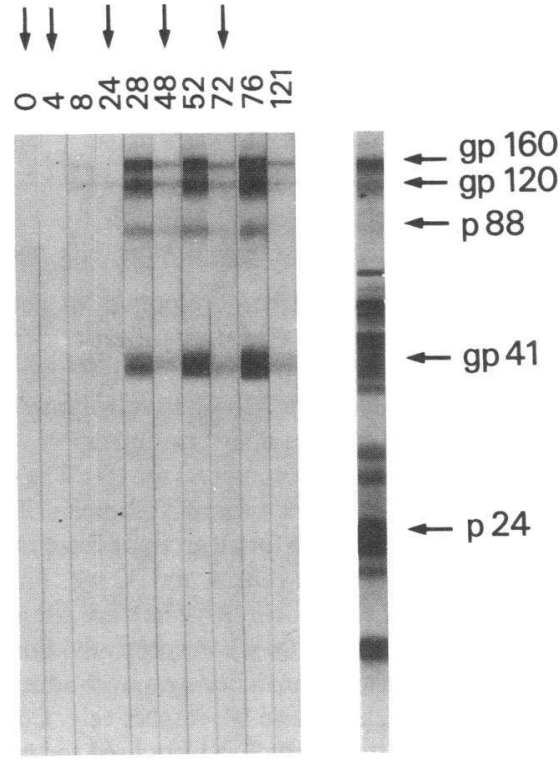

$1280 \mu \mathrm{g}$

Figure 1. Immunoblots of sequential sera from four volunteers with strong antibody responses after immunization with rgp 160 . The dose of immunogen is shown along the bottom and weeks after the primary immunization are shown along the top; time of administration of immunizations is indicated by arrows. An immunoblot from an HIV-infected patient is in the right lane. The location of individual HIV envelope proteins is shown along the right. Immunoblot reactivity was determined using a commercially available kit (DuPont Co.) with sera (1:100) obtained at the indicated time points. 

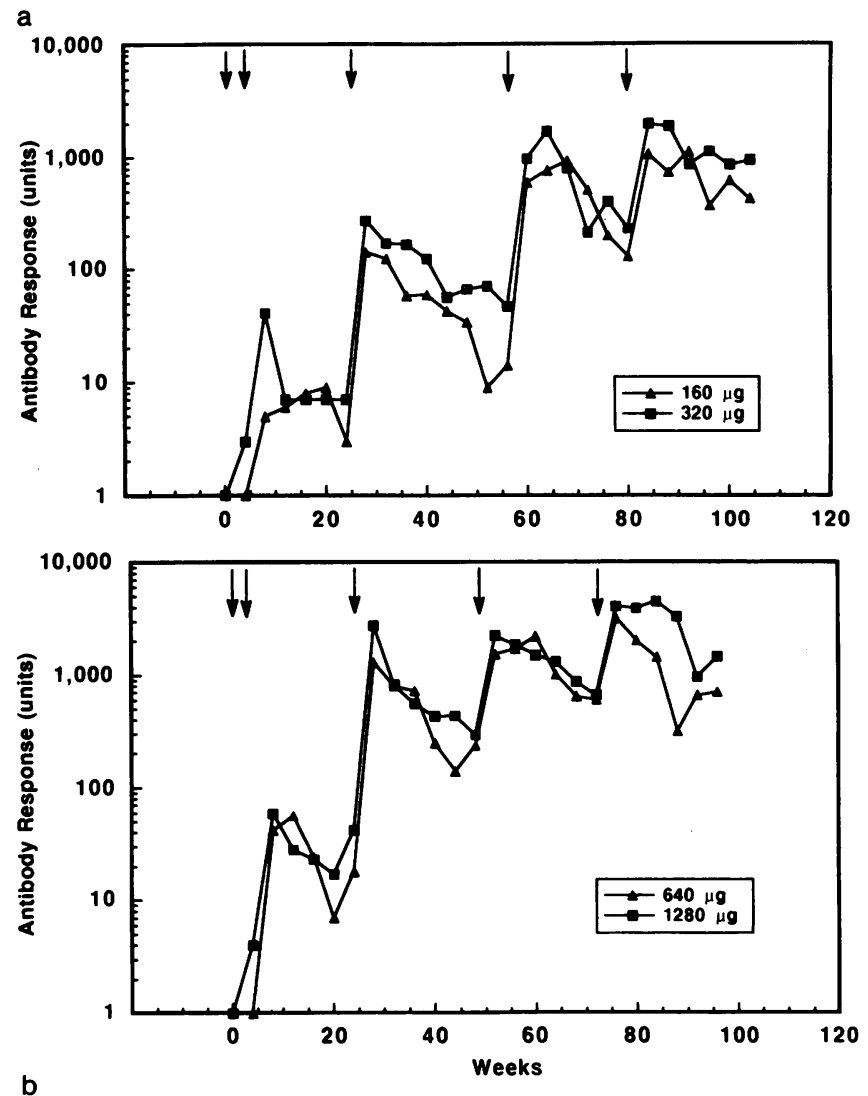

b

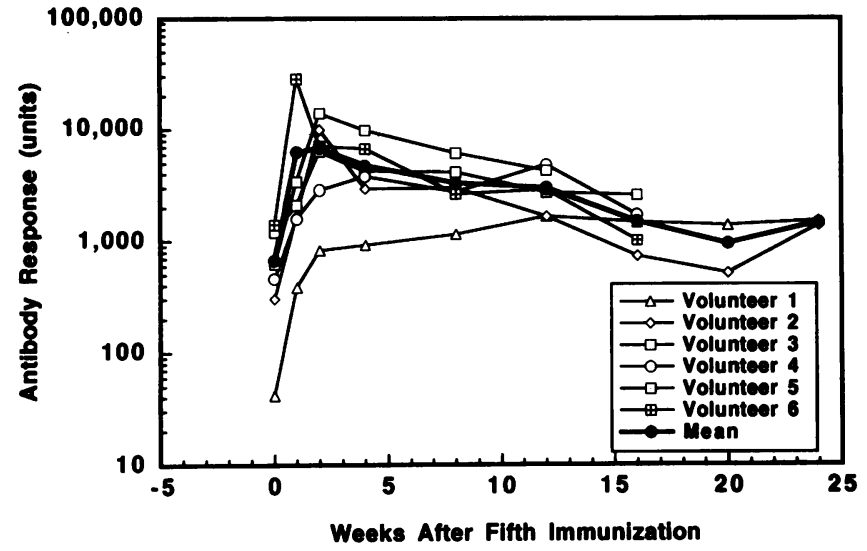

Figure 2. (a) Mean antibody responses, as determined by ELISA (Abbott Laboratories), after immunization with five doses of 160 $1,280 \mu \mathrm{g}$ rgp 160. The top shows responses after immunization with 160 (four volunteers) or $320 \mu \mathrm{g}$ (five volunteers) rgp 160, and the bottom shows responses after immunization with 640 (three volunteers) or $1,280 \mu \mathrm{g}$ (six volunteers) rgp 160. The first booster immunization was given at week 4 for all volunteers. The second booster was administered at week 24 for all groups except the $160-\mu$ g group, who received this boost between 24 and 32 wk. For the 160 - and $320-\mu \mathrm{g}$ groups, the third and fourth boosters were administered between 60 and $72 \mathrm{wk}$ and 84 and $100 \mathrm{wk}$, respectively. For the $640-$ and $1,280-\mu \mathrm{g}$ groups, the third and fourth boosters were administered at week 48 and between weeks 71 and 84, respectively. Comparable time points relative to each immunization were used for calculating the mean ELISA results. Although there was variability in the actual time of immunization, immunization times have been standardized on the graph to allow comparability among the groups. For the top graph, the five immunizations have been standardized, as indicated by the arrows, to weeks $0,4,24,56$, and 80 and for the bottom graph to weeks $0,4,24,48$, and 72 . (b) Antibody responses after the fifth immunization with 640 (one volunteer) or $1,280 \mu \mathrm{g}$ (five volunteers).
Table II. Epitope Responses in Immunized Volunteers and HIV-Positive Patients, as Determined by Western Blots

\begin{tabular}{|c|c|c|}
\hline Epitope & $\begin{array}{l}\text { rgp160 immunized } \\
(n=18)\end{array}$ & $\begin{array}{l}\text { HIV infected } \\
\quad(n=56)\end{array}$ \\
\hline & \multicolumn{2}{|c|}{$\%$} \\
\hline C1 (49-128) & 83 & 27 \\
\hline C2 (254-274) & 39 & 0 \\
\hline V3 $(300-340)$ & 72 & 41 \\
\hline C3 (342-405) & 44 & 0 \\
\hline CD4 (422-454) & 39 & 2 \\
\hline C448 (453-518) & 89 & 93 \\
\hline C41 (579-605) & 94 & 96 \\
\hline CKen (735-752) & 33 & 11 \\
\hline
\end{tabular}

Antibody responses to gp 160 epitopes in 18 volunteers immunized with rgp160 $(160-1,280 \mu \mathrm{g})$. Sera (diluted 1:1,000) obtained 1 mo after the fourth immunization were assayed by immunoblot. A distinctly positive reaction on immunoblot to a gp160 epitope fusion protein was scored as positive $(+)$, and no detectable reaction as negative $(-)$ for antibodies to that particular epitope. Sera obtained before immunization did not react with fusion proteins; sera obtained after two immunizations with 40 or $80 \mu \mathrm{g}$ rgp 160 were also nonreactive. Responses for $56 \mathrm{HIV}$-infected patients are provided for comparison.

Neụtralization of the LAV isolate of HIV was evaluated using one to three serum samples obtained 31-83 wk after initial immunization from the 11 volunteers that showed maximal ELISA reactivity. None of the six volunteers in the 320 - or 640- $\mu$ g groups who were tested developed neutralizing antibodies. Four of five volunteers in the $1,280 \mu \mathrm{g}$ group developed neutralizing titers of 1:4-1:8 compared with neutralizing titers of 1:16-1:256 seen in HIV-infected patients (Fig. 4). End point dilution titers to specific epitopes were determined by ELISA; all three volunteers with titers of 1:400 to the V3 loop showed neutralizing antibodies, whereas only one volunteer with a lower titer had neutralizing activity (Table III). No neutralization was seen with any of the sera from vaccinated subjects when the HIV $_{\mathbf{M N}}, \mathrm{HIV}_{\mathbf{R F}}$, or $\mathrm{HIV}_{\mathbf{S F}}$ isolates were used. No inhibition of syncytia formation was seen when sera (1:10) from 15 volunteers immunized with 320,640 , or $1,280 \mu \mathrm{g}$, including 3 whose sera neutralized in the MT2 assay, were evaluated in a cell fusion inhibition assay performed by an NIAID central immunology laboratory.

Blastogenic responses to rgp 160 were consistently seen in a majority of the patients after two immunizations with $20 \mu \mathrm{g}$ rgp 160 or higher, and the responses were usually sustained for over 1 yr. Sustained responses were occasionally seen after a single immunization, especially at doses $>160 \mu \mathrm{g}$. The mean responses for the volunteers who received 6-mo booster immunizations are summarized according to dose group in Fig. $5 a$ (top). Blastogenic responses were also seen to rgp160 derived from a heterologous HIV isolate ( $\mathrm{HIV}_{\mathrm{NY}-5}$ ) but not from SIV (Fig. $5 b$ ).

Among the randomized patients in the second part of the study, an antibody response similar to that seen in the $320-\mu \mathrm{g}$

Responses were determined by ELISA as in $a$. Results are shown for the individual volunteers by the open symbols; mean results for the group are depicted by the closed circles. 
Dose/Boost

Day 0

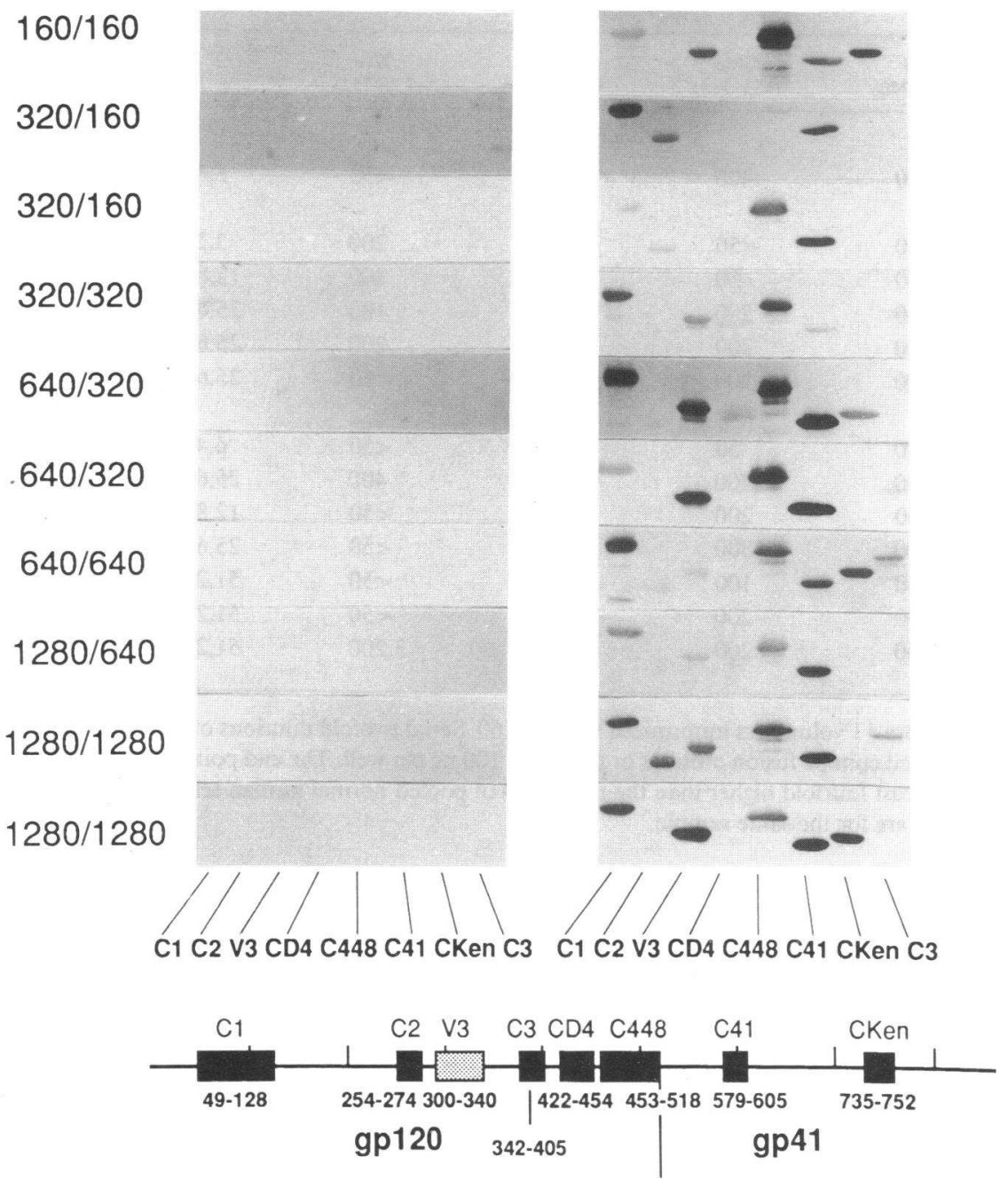

Month 13-20

Figure 3. Epitope antibody responses after immunization with rgp 160. Serum samples from day 0 (preimmunization) and $1 \mathrm{mo}$ after the fourth immunization (months 13-19) were tested by immunoblot for antibodies to purified $E$. coli malE-gp160 epitope fusion proteins (47). The location and amino acid position of the gp 160 epitopes are illustrated at the bottom of the figure. Responses for 10 volunteers are shown. The first column indicates the dose of the first two immunizations. The third and fourth immunizations used the primary dose.

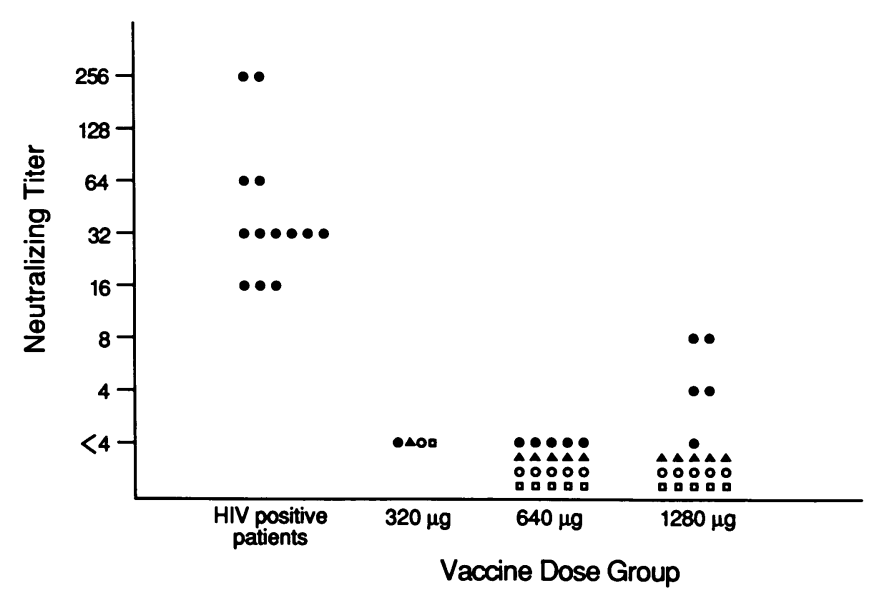

Figure 4. Neutralization of HIV isolates after immunization with rgp160. Sera from 11 patients showing the highest ELISA reactivity after immunization with 320-1,280 $\mu \mathrm{g}$ rgp 160 were assayed for their ability to neutralize four HIV isolates in tissue culture. For comparison, sera from 13 randomly selected HIV-infected patients were evaluated in the same assay. Isolates are as follows: $\mathrm{HIV}_{\mathbf{L A V}}, \bullet ; \mathrm{HIV}_{\mathbf{M N}}$, $\triangle ; \mathrm{HIV}_{\mathrm{RF}}, \circ ; \mathrm{HIV}_{\mathbf{S F}}, \mathrm{\square}$. group was seen in those volunteers receiving rgp 160 (results not shown). No differences in antibody responses were seen between the heterosexual and homosexual/bisexual volunteers immunized with rgp 160 when evaluated by ELISA: mean peak titers for the two groups were 1,080 and 1,207 $\mathrm{U}$, respectively. No antibody response was seen in the control group. Blastogenic responses to rgp 160 occurred in the rgp 160 group but not in the KLH group (Fig. 5 a, bottom).

Immunization with rgp160 was well tolerated. The most common side effects attributable to immunization included local soreness and redness at the site of immunization, fever, and flu-like symptoms (Table IV). Reactions, primarily soreness, were more frequent among volunteers receiving the higher doses of rgp160. No consistent changes in hematology or chemistry values were seen. Three patients developed medical problems during the course of the study that were not felt to be related to immunization. One volunteer in the $10-\mu \mathrm{g}$ group developed an inflammatory process characterized by weight loss, diarrhea, arthralgias, myalgias, fever, and fatigue that lasted for $\sim 1 \mathrm{yr}$ and ultimately responded to nonsteroidal antiinflammatory agents. A second volunteer (20- $\mu$ g group) developed transient hematuria in association with an elevated 


\begin{tabular}{|c|c|c|c|c|c|c|c|c|}
\hline \multirow[b]{2}{*}{ Dose/volunteer } & \multirow[b]{2}{*}{ Week } & \multicolumn{6}{|c|}{ gp160 Epitope } & \multirow[b]{2}{*}{$\begin{array}{c}\text { Neutralizing } \\
\text { titer }\end{array}$} \\
\hline & & $\begin{array}{c}\mathrm{Cl} \\
(49-128)\end{array}$ & $\begin{array}{c}\text { V3 } \\
(300-340)\end{array}$ & $\begin{array}{c}\text { C448 } \\
(453-518)\end{array}$ & $\begin{array}{c}\text { C41 } \\
(579-605)\end{array}$ & $\begin{array}{c}\text { CKen } \\
(735-752)\end{array}$ & rgp 160 & \\
\hline \multicolumn{9}{|l|}{$320 \mu \mathrm{g}$} \\
\hline 1 & 96 & 400 & 50 & 400 & 200 & $<50$ & 6,400 & $<4$ \\
\hline \multicolumn{9}{|l|}{$640 \mu \mathrm{g}$} \\
\hline 2 & 52 & $<50$ & $<50$ & $<50$ & 100 & 200 & 3,200 & $<4$ \\
\hline 3 & 56 & 50 & 50 & 50 & 50 & 200 & 12,800 & $<4$ \\
\hline 4 & 52 & 50 & 200 & 200 & 100 & 100 & 25,600 & $<4$ \\
\hline 5 & 86 & 400 & 200 & 200 & 800 & 200 & 25,600 & $<4$ \\
\hline 6 & 52 & 400 & 200 & 200 & 800 & $<50$ & 25,600 & $<4$ \\
\hline \multicolumn{9}{|l|}{$1,280 \mu \mathrm{g}$} \\
\hline 7 & 32 & 200 & 200 & 50 & 50 & $<50$ & 6,400 & $<4$ \\
\hline 7 & 74 & 1,600 & 400 & 400 & 200 & 400 & 25,600 & 4 \\
\hline 8 & 60 & $<50$ & $<50$ & 200 & 200 & $<50$ & 12,800 & $<4$ \\
\hline 9 & 52 & 400 & 400 & 800 & 400 & $<50$ & 25,600 & 8 \\
\hline 10 & 28 & 200 & 50 & 100 & 800 & $<50$ & 51,200 & 8 \\
\hline 10 & 78 & 400 & 50 & 200 & 200 & $<50$ & 51,200 & $<4$ \\
\hline 11 & 74 & 1,600 & 400 & 200 & 1,600 & 3,200 & 51,200 & 4 \\
\hline
\end{tabular}

End point dilution titers to epitopes of gp 160 for sera from 11 volunteers immunized with rgp 160 . Serial twofold dilutions of sera, starting at 1:50, were evaluated by ELISA using plates coated with purified epitope fusion proteins or rgp 160 at $100 \mathrm{ng}$ per well. The end point titer was defined as the titer that gave an $\mathrm{OD} \geq 0.05$, which was also at least fourfold higher than the mean OD of pooled normal human serum. Weeks indicates time after primary immunization. Neutralization titers are for the same sample.

prothrombin time that normalized after parenteral administration of vitamin K. 5 mo after the initial immunization, a third volunteer (320- $\mu$ g group) developed left-sided weakness and numbness, a tremor, and an episode of blurred vision, which was diagnosed as multiple sclerosis. In retrospect he had similar visual symptoms 6 yr before immunization.

Concerns about the potential toxicity of HIV envelope protein to CD4 cells have been raised $(1,58,59)$. In this study, no immunologic changes were seen after immunization with rgp 160. Specifically, no significant changes in CD4 or CD8 number were seen. CD4 and CD8 values for the 1,280- $\mu \mathrm{g}$ group during 1 yr of follow-up are shown in Fig. 6, top. Additionally, no changes in natural killer cell activity or in blastogenic responses to tetanus toxoid or phytohemagglutinin were seen (data not shown). Among the patients randomized to KLH or gp 160, no significant differences were seen among the groups in any of the laboratory parameters evaluated, including the immune parameters. The changes in CD4 counts for these two groups are shown in Fig. 6, bottom.

Two patients who received a single dose of 10 and $40 \mu \mathrm{g}$ rgp 160 became HIV seropositive, 4 yr and 1 yr after immunization, respectively, with a positive ELISA and a Western blot pattern typical of HIV infection. Before seroconversion, they had shown no antibody or blastogenic response to immunization. Their subsequent clinical course has been unremarkable.

\section{Discussion}

This study has clearly demonstrated that rgp 160 is a safe and immunogenic vaccine candidate that is capable of inducing neutralizing antibodies as well as blastogenic responses in a dose-dependent manner, with the optimal immunizing regi- men being three doses of $1,280 \mu \mathrm{g}$ rgp 160 administered at 0,1 , and $6 \mathrm{mo}$. This regimen will induce a sustained blastogenic response as well as antibodies that decline in titer over the course of a year but that can rapidly be reinduced. Although the current vaccine preparation clearly is immunogenic, the degree of protection conferred will ultimately be determined only by a randomized trial.

Immunization with the rgp160 preparation used in this study has also been shown to induce new humoral and cell-mediated responses in patients with HIV infection, responses which may be associated with immunologic stabilization (48). The latter study suggests that a major advantage of rgp160 is the unique presentation, compared with naturally acquired infection, of potentially important envelope epitopes. In this study we have shown that HIV-seronegative volunteers will also develop antibodies to these epitopes with a greater frequency than is seen in naturally acquired infection. Which of these epitopes, if any, are important in inducing protection against infection is unknown at present, and it is possible that antibodies to these epitopes have no clinical significance. Our data support the suggestion, however, that development of anti-V3 antibodies after immunization is associated with neutralization of the homologous viral isolate, and at least one study has shown that an anti-V3 neutralizing $\mathrm{mAb}$ can prevent HIV infection (46). Neutralizing titers were lower than seen in naturally acquired infection; however, the level of neutralizing antibodies needed for protection of HIV-negative individuals is currently unknown. Although the current rgp 160 preparation was effective in neutralizing only the homologous LAV isolate, the use of an rgp160 sequence derived from one or more endemic strains should allow induction of a more clinically relevant neutralizing response. A previous report found neutralizing antibodies after immunization with low doses of rgp 160 in 

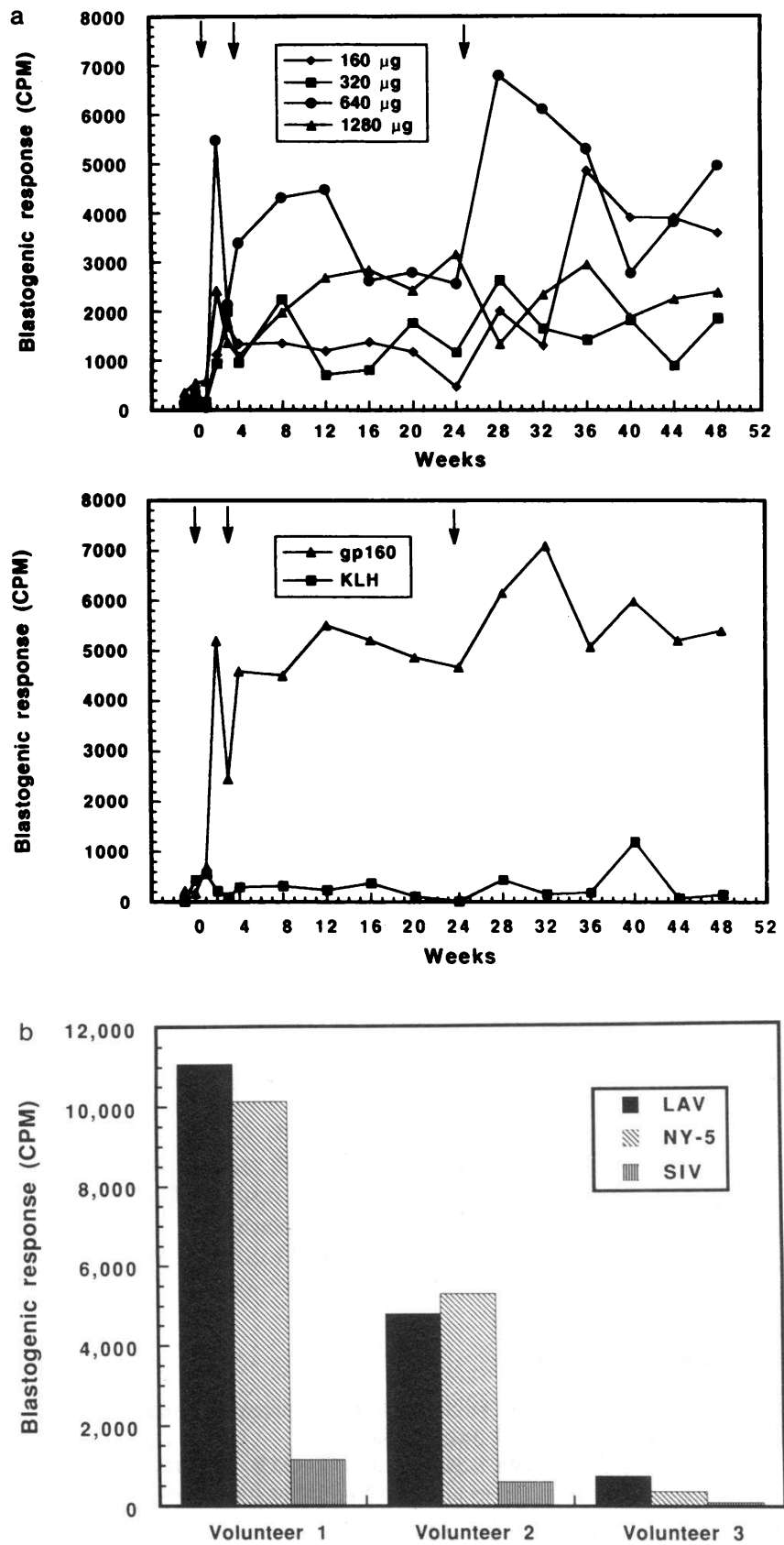

Figure 5. (a) Blastogenic responses to rgp160 after immunization with rgp 160. Top graph shows results for the 23 volunteers who received three immunizations of $160-1,280 \mu \mathrm{g}$ rgp160. Bottom graph shows results for the volunteers randomized to three doses of rgp 160 ( 320 $\mu \mathrm{g})$ or KLH $(320 \mu \mathrm{g})$. Results shown are for cryopreserved cells assayed using $5 \mu \mathrm{g} / \mathrm{ml} \mathrm{rgp} 160$ as the stimulus and are expressed as net cpm of $\left[{ }^{3} \mathrm{H}\right]$ thymidine incorporated per $10^{5}$ cells. $(b)$ Blastogenic response to heterologous viral isolates. Responses to rgp $160_{\mathrm{LAV}}$, rgp $160_{\mathrm{NY}-5}$, and rgp140 ${ }_{\mathrm{SIV}}$ were evaluated in three volunteers $8 \mathrm{wk}$ after the primary immunization with $320 \mu \mathrm{g} \mathrm{rgp} 160$. Volunteer 1 received no booster immunization at week 4; volunteers 2 and 3 received $320 \mu \mathrm{g}$ at week 4 . Volunteers 1 and 2 showed responses to both LAV and NY-5-derived envelope protein, but not SIV-derived envelope protein. Volunteer 3 showed responses to none of the three.

a minority of volunteers (47); in the current study no neutralizing antibodies were seen after immunization at those doses. This may be because of differences in study population or, more likely, in the assay technique used for measuring neutralization.

In studies of SIV vaccines efficacy was demonstrated despite induction of only low levels of neutralizing antibodies when compared with levels induced after infection with SIV (32-34). Although protection in many of these studies appears to have depended on the development of anticellular antibodies (37-41), one report has demonstrated protection after immunization with recombinant subunit envelope vaccines (42).

Blastogenic responses to gp 160 were induced earlier and by lower doses of rgp 160 than were necessary for antibody induction. Although small amounts of baculovirus-derived proteins may have contaminated the immunogen, the proliferative responses were specific for gp160 and not contaminating proteins, because no blastogenic response was seen to baculovirus proteins alone in patients showing proliferative responses to gp160. Additionally, patients showed proliferation to recombinant HIV-derived envelope proteins but not identically prepared SIV-derived proteins. Finally, blastogenic responses were also seen to vaccinia-generated HIV envelope proteins, which contained no baculovirus products (data not shown).

Although no other studies have used doses of rgp160 as high as those used in the current study, other investigators have also found blastogenic responses after immunization with low doses of rgp160 (60-63). Furthermore, in characterizing these $T$ cell responses, $C D 4$ positive, but not $C D 8$ positive, cytolytic $T$ cells specific for HIV have been identified and cloned, and a conserved $T$ cell epitope in gp41 has been shown to be recognized by some of these clones (64-66). Immunization has also been associated with T helper responses, as shown by IL-2 production, to envelope-derived peptides. Thus, immunization with rgpl60 can induce potentially beneficial cell-mediated immune responses.

A major goal of this study, the first vaccine trial initiated in the United States, was to demonstrate the safety and the immunogenicity of a candidate HIV vaccine, thus providing strong support for the initiation of further vaccine trials in both seronegative and seropositive individuals $(47,48)$. No adverse events other than those commonly seen after immunization with other vaccine preparations were attributable to rgp 160. Specifically, there was no evidence of an immunosuppressive effect of rgp 160, even after five immunizations with the highest dose used in this trial.

Given the urgency of developing an effective vaccine and the demonstrated safety and immunogenicity of rgp 160, phase II trials of rgp 160 (genetically engineered to resemble endemic strains) as well as of other candidate HIV vaccines should proceed quickly and should be expeditiously followed by randomized, blinded phase III trials of the most promising candidate vaccine(s). Such trials are needed to define the true clinical utility of vaccine preparations. In this regard, utility can be defined not only as a vaccine that can prevent infection but also one that can slow the rate of progression after infection. Although the immune mechanisms needed for protection against HIV have not yet been identified, delaying efficacy trials until protective mechanisms have been clearly elucidated is not warranted, because these mechanisms may not be defined for many years. This study, as well as others evaluating potential HIV vaccine candidates $(47,67-70)$, have established the feasibility of proceeding to randomized trials, and definitive establishment of efficacy will ultimately be provided only by such a trial. 


\begin{tabular}{|c|c|c|c|c|c|c|c|c|}
\hline \multirow[b]{2}{*}{ Dose } & \multirow[b]{2}{*}{$\begin{array}{c}\text { No. of } \\
\text { immunizations }\end{array}$} & \multicolumn{7}{|c|}{ Adverse events } \\
\hline & & None & Soreness & Fever & $\begin{array}{l}\text { Local } \\
\text { redness }\end{array}$ & $\begin{array}{l}\text { Flu-like } \\
\text { symptoms }\end{array}$ & $\begin{array}{c}\text { Joint } \\
\text { pain }\end{array}$ & Other* \\
\hline $10 \mu \mathrm{g}$ & 23 & 18 & 1 & 1 & 1 & 0 & 0 & 1 \\
\hline $20 \mu \mathrm{g}$ & 25 & 14 & 6 & 4 & 2 & 1 & 1 & 1 \\
\hline $40 \mu \mathrm{g}$ & 35 & 21 & 3 & 1 & 0 & 0 & 0 & 0 \\
\hline $80 \mu \mathrm{g}$ & 33 & 24 & 4 & 0 & 1 & 3 & 0 & 1 \\
\hline $160 \mu \mathrm{g}$ & 37 & 23 & 10 & 1 & 0 & 2 & 0 & 1 \\
\hline $320 \mu \mathrm{g}$ & 41 & 24 & 12 & 2 & 0 & 1 & 1 & 1 \\
\hline $640 \mu \mathrm{g}$ & 39 & 19 & 18 & 3 & 2 & 3 & 2 & 0 \\
\hline $1,280 \mu \mathrm{g}$ & 43 & 21 & 22 & 0 & 1 & 2 & 1 & 0 \\
\hline \multicolumn{9}{|c|}{ Randomized } \\
\hline $\mathrm{KLH}$ & 34 & 23 & 9 & 1 & 0 & 1 & 0 & 0 \\
\hline gp160 & 31 & 11 & 16 & 2 & 2 & 2 & 0 & 0 \\
\hline
\end{tabular}

* One each: inflammatory process, hematuria, multiple sclerosis, myalgia, nausea; the first three were not attributed to immunization. Adverse events that occurred after immunization with rgp 160. For each dose level, adverse events after all immunizations (primary and boosters) have been combined. Total number of immunizations at each dose level are indicated in the second column.
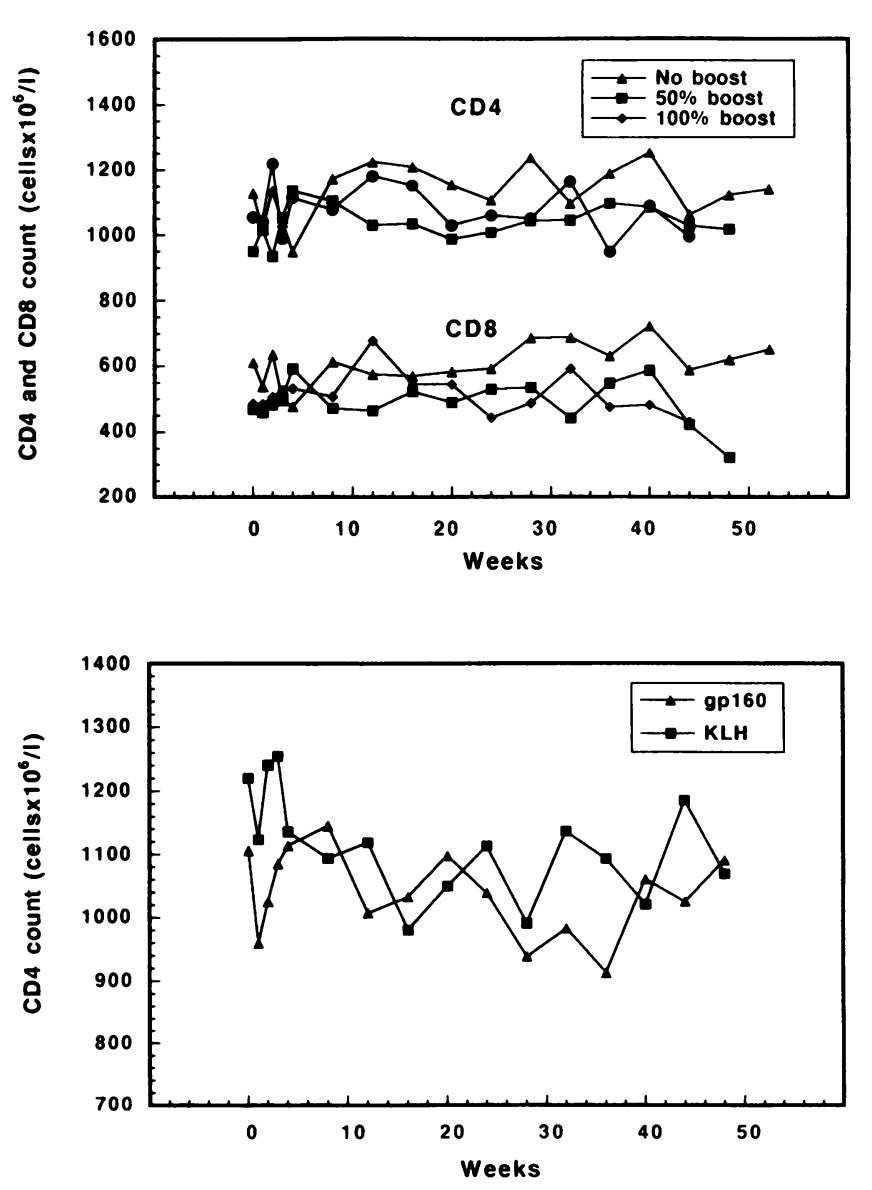

Figure 6. Changes in CD4 and CD8 cell counts after immunization with rgp 160. Top panel shows CD4 and CD8 counts for the $1,280-\mu \mathrm{g}$ group. Each line represents the five patients who received no boost, $50 \%$ boost, or $100 \%$ boost at $4 \mathrm{wk}$. 6 of the 10 volunteers in the latter two groups also received an additional $100 \%(1,280 \mu \mathrm{g})$ boost at 24 wk. Bottom panel shows CD4 counts over time for the 15 volunteers who received three doses of $320 \mu \mathrm{g} \mathrm{rgp} 160$ or $\mathrm{KLH}$ in a randomized manner.

\section{Acknowledgment}

We thank Dr. Anthony S. Fauci for his support and suggestions.

Research sponsored in part by the National Cancer Institute, Department of Health and Human Services (DHHS), under contract NO1-CO-74102 with Program Resources, Incorporated/DynCorp. The contents of this publication do not necessarily reflect the views of the DHHS, nor does mention of trade names, commercial products, or organizations imply endorsement by the US Government.

Note added in proof: One additional volunteer has recently become HIV seropositive. He was immunized with $640 \mu \mathrm{g}$, and received three booster immunizations, with a good antibody response that decreased during 6 mo of follow-up, as well as good blastogenic responses to rgp 160. HIV infection was documented by ELISA and Western blot $\sim 3 \mathrm{yr}$ after his last immunization.

\section{References}

1. Koff, W. C., and D. F. Hoth. 1988. Development and testing of AIDS vaccines. Science (Wash. DC). 241:426-432.

2. Fauci, A. S., R. C. Gallo, S. Koenig, J. Salk, and R. H. Purcell. 1989. NIH conference. Development and evaluation of a vaccine for human immunodeficiency virus (HIV) infection. Ann. Intern. Med. 110:373-385.

3. Fauci, A. S., and P. J. Fischinger. 1988. The development of an AIDS vaccine: progress and promise. Public Health Rep. 103:230-236.

4. Bolognesi, D. P. 1989. Progress in vaccines against AIDS. Science (Wash. DC). 246:1233-1234.

5. Bolognesi, D. P. 1991. AIDS vaccines: progress and unmet challenges. Ann. Intern. Med. 114:161-162.

6. Fischl, M. A., C. B. Parker, C. Pettinelli, M. Wulfsohn, M. S. Hirsch, A. C. Collier, D. Antoniskis, M. Ho, D. D. Richman, E. Fuchs et al. 1990. A randomized controlled trial of a reduced daily dose of zidovudine in patients with the acquired immunodeficiency syndrome. The AIDS Clinical Trials Group. $N$. Engl. J. Med. 323:1009-1014.

7. Fischl, M. A., D. D. Richman, M. H. Grieco, M. S. Gottlieb, P. A. Volberding, O. L. Laskin, J. M. Leedom, J. E. Groopman, D. Mildvan, R. T. Schooley et al. 1987. The efficacy of azidothymidine (AZT) in the treatment of patients with AIDS and AIDS-related complex. A double-blind, placebo-controlled trial. $N$. Engl. J. Med. 317:185-191.

8. Fischl, M. A., D. D. Richman, N. Hansen, A. C. Collier, J. T. Carey, M. F Para, W. D. Hardy, R. Dolin, W. G. Powderly, J. D. Allan et al. 1990. The safety and efficacy of zidovudine (AZT) in the treatment of subjects with mildly symptomatic human immunodeficiency virus type 1 (HIV) infection. A double-blind placebo-controlled trial. The AIDS Clinical Trials Group. Ann. Intern. Med. 112:727-737. 
9. Merigan, T. C., G. Skowron, S. A. Bozzette, D. Richman, R. Uttamchandani, M. Fischl, R. Schooley, M. Hirsch, W. Soo, C. Pettinelli et al. 1989. Circulating p24 antigen levelsand responses to dideoxycytidine in human immunodeficiency virus (HIV) infections. A phase I and II study. Ann. Intern. Med. 110:189194.

10. Yarchoan, R., J. M. Pluda, R. V. Thomas, H. Mitsuya, P. Brouwers, K. M. Wyvill, N. Hartman, D. G. Johns, and S. Broder. 1990. Long-term toxicity/activity profile of $2^{\prime}, 3^{\prime}$-dideoxyinosine in AIDS or AIDS-related complex. Lancet. 336:526-529.

11. Yarchoan, R., H. Mitsuya, R. V. Thomas, J. M. Pluda, N. R. Hartman, C. F. Perno, K. S. Marczyk, J. P. Allain, D. G. Johns, and S. Broder. 1989. In vivo activity against HIV and favorable toxicity profile of $2^{\prime}, 3$ '-dideoxyinosine. Science (Wash. DC). 245:412-415.

12. Ho, D. D., J. C. Kaplan, I. E. Rackauskas, and M. E. Gurney. 1988. Second conserved domain of gp 120 is important for HIV infectivity and antibody neutralization. Science (Wash. DC). 239:1021-1023.

13. Javaherian, K., A. J. Langlois, G. J. LaRosa, A. T. Profy, D. P. Bolognesi, W. C. Herlihy, S. D. Putney, and T. J. Matthews. 1990. Broadly neutralizing antibodies elicited by the hypervariable neutralizing determinant of HIV-1. Science (Wash. DC). 250:1590-1593.

14. Javaherian, K., A. J. Langlois, C. McDanal, K. L. Ross, L. I. Eckler, C. L. Jellis, A. T. Profy, J. R. Rusche, D. P. Bolognesi, S. D. Putney et al. 1989. Principal neutralizing domain of the human immunodeficiency virus type 1 envelope protein. Proc. Natl. Acad. Sci. USA. 86:6768-6772.

15. LaRosa, G. J., J. P. Davide, K. Weinhold, J. A. Waterbury, A. T. Profy, J. A. Lewis, A. J. Langlois, G. R. Dreesman, R. N. Boswell, P. Shadduck et al. 1990. Conserved sequence and structural elements in the HIV-1 principal neutralizing determinant. Science (Wash. DC). 249:932-935.

16. Putney, S. D., T. J. Matthews, W. G. Robey, D. L. Lynn, M. Robert Guroff, W. T. Mueller, A. J. Langlois, J. Ghrayeb, S. R. Petteway, K. J. Weinhold et al. 1986. HTLV-III/LAV-neutralizing antibodies to an E. coli-produced fragment of the virus envelope. Science (Wash. DC). 234:1392-1395.

17. Weiss, R. A., P. R. Clapham, J. N. Weber, A. G. Dalgleish, L. A. Lasky, and P. W. Berman. 1986. Variable and conserved neutralization antigens of human immunodeficiency virus. Nature (Lond.). 324:572-575.

18. Sawyer, L. A., D. A. Katzenstein, R. M. Hendry, E. J. Boone, L. K. Vujcic, C. C. Williams, S. L. Zeger, A. J. Saah, C. R. Rinaldo, J. P. Phair et al. 1990. Possible beneficial effects of neutralizing antibodies and antibody-dependent, cell-mediated cytotoxicity in human immunodeficiency virus infection. AIDS Res. Hum. Retroviruses. 6:341-356.

19. Koenig, S., P. Earl, D. Powell, G. Pantaleo, S. Merli, B. Moss, and A. S. Fauci. 1988. Group-specific, major histocompatibility complex class I-restricted cytotoxic responses to human immunodeficiency virus 1 (HIV-1) envelope proteins by cloned peripheral blood T cells from an HIV-1-infected individual. Proc. Natl. Acad. Sci. USA 85:8638-8642.

20. Walker, B. D., S. Chakrabarti, B. Moss, T. J. Paradis, T. Flynn, A. G. Durno, R. S. Blumberg, J. C. Kaplan, M. S. Hirsch, and R. T. Schooley. 1987. HIV-specific cytotoxic T lymphocytes in seropositive individuals. Nature (Lond.). 328:345-348.

21. Walker, C. M., D. J. Moody, D. P. Stites, and J. A. Levy. 1986. CD8+ lymphocytes can control HIV infection in vitro by suppressing virus replication. Science (Wash. DC). 234:1563-1566.

22. Weinhold, K. J., H. K. Lyerly, T. J. Matthews, D. S. Tyler, P. M. Ahearne, K. C. Stine, A. J. Langlois, D. T. Durack, and D. P. Bolognesi. 1988. Cellular anti-GP120 cytolytic reactivities in HIV-1 seropositive individuals. Lancet. 1:902-905.

23. Ahearne, P. M., T. J. Matthews, H. K. Lyerly, G. C. White, D. P. Bolognesi, and K. J. Weinhold. 1988. Cellular immune response to viral peptides in patients exposed to HIV. AIDS Res. Hum. Retroviruses. 4:259-267.

24. Tyler, D. S., S. D. Stanley, C. A. Nastala, A. A. Austin, J. A. Bartlett, K. C. Stine, H. K. Lyerly, D. P. Bolognesi, and K. J. Weinhold. 1990. Alterations in antibody-dependent cellular cytotoxicity during the course of HIV-1 infection. Humoral and cellular defects. J. Immunol. 144:3375-3384.

25. Belo, M., M. Yagello, M. Girard, R. Greenlee, A. Deslandres, F. Barre Sinoussi, and J. C. Gluckman. 1991. Antibody-dependent cellular cytotoxicity against HIV-1 in sera of immunized chimpanzees. AIDS (Phila.). 5:169-176.

26. Evans, L. A., G. Thomson Honnebier, K. Steimer, E. Paoletti, M. E. Perkus, H. Hollander, and J. A. Levy. 1989. Antibody-dependent cellular cytotoxicity is directed against both the gp 120 and gp41 envelope proteins of HIV. AIDS (Phila.). 3:273-276.

27. Koup, R. A., J. L. Sullivan, P. H. Levine, F. Brewster, A. Mahr, G. Mazzara, S. McKenzie, and D. Panicali. 1989. Antigenic specificity of antibodydependent cell-mediated cytotoxicity directed against human immunodeficiency virus in antibody-positive sera. J. Virol. 63:584-590.

28. Lyerly, H. K., D. L. Reed, T. J. Matthews, A. J. Langlois, P. A. Ahearne, S. R. Petteway, and K. J. Weinhold. 1987. Anti-GP 120 antibodies from HIV seropositive individuals mediate broadly reactive anti-HIV ADCC. AIDS Res. Hum. Retroviruses. 3:409-422.
29. Tyler, D. S., H. K. Lyerly, and K. J. Weinhold. 1989. Anti-HIV-1 ADCC. AIDS Res. Hum. Retroviruses. 5:557-563.

30. Looney, D. J., A. G. Fisher, S. D. Putney, J. R. Rusche, R. R. Redfield, D. S. Burke, R. C. Gallo, and F. Wong Staal. 1988. Type-restricted neutralization of molecular clones of human immunodeficiency virus. Science (Wash. DC). 241:357-359.

31. Matthews, T. J., A. J. Langlois, W. G. Robey, N. T. Chang, R. C. Gallo, P. J. Fischinger, and D. P. Bolognesi. 1986. Restricted neutralization of divergent human T-lymphotropic virus type III isolates by antibodies to the major envelope glycoprotein. Proc. Natl. Acad. Sci. USA. 83:9709-9713.

32. Murphey Corb, M., L. N. Martin, B. Davison Fairburn, R. C. Montelaro, M. Miller, M. West, S. Ohkawa, G. B. Baskin, J. Y. Zhang, S. D. Putney et al. 1989. A formalin-inactivated whole SIV vaccine confers protection in macaques. Science (Wash. DC). 246:1293-1297.

33. Desrosiers, R. C., M. S. Wyand, T. Kodama, D. J. Ringler, L. O. Arthur, P. K. Sehgal, N. L. Letvin, N. W. King, and M. D. Daniel. 1989. Vaccine protection against simian immunodeficiency virus infection. Proc. Natl. Acad. Sci. USA. 86:6353-6357.

34. Carlson, J. R., T. P. McGraw, E. Keddie, J. L. Yee, A. Rosenthal, A. J. Langlois, R. Dickover, R. Donovan, P. A. Luciw, M. B. Jennings et al. 1990. Vaccine protection of rhesus macaques against simian immunodeficiency virus infection. AIDS Res. Hum. Retroviruses. 6:1239-1246.

35. Daniel, M. D., F. Kirchhoff, S. C. Czajak, P. K. Sehgal, and R. C. Desrosiers. 1992. Protective effects of a live attenuated SIV vaccine with a deletion in the nef gene. Science (Wash. DC). 258:1938-1941.

36. Murphey Corb, M., R. C. Montelaro, M. A. Miller, M. West, L. N. Martin, B. Davison Fairburn, S. Ohkawa, G. B. Baskin, J. Y. Zhang et al. 1991. Efficacy of SIV/deltaB670 glycoprotein-enriched and glycoprotein-depleted subunit vaccines in protecting against infection and disease in rhesus monkeys. AIDS (Phila.). 5:655-662.

37. Stott, E. J., W. L. Chan, K. H. Mills, M. Page, F. Taffs, M. Cranage, P. Greenaway, and P. Kitchin. 1990. Preliminary report: protection of cynomolgus macaques against simian immunodeficiency virus by fixed infected-cell vaccine. Lancet. 336:1538-1541.

38. Stott, E. J. 1991. Anti-cell antibody in macaques. Nature (Lond.). 353:393.

39. Le Grand, R., B. Vaslin, G. Vogt, P. Roques, M. Humbert, D. Dormont, and A. M. Aubertin. 1992. AIDS Vaccine developments. Nature (Lond.). 355:684.

40. Osterhaus, A., P. deVries, and J. Heeney. 1992. AIDS vaccine developments. Nature (Lond.). 355:684-685.

41. Cranage, M. R., L. A. E. Ashworth, P. J. Greenaway, M. Murphey-Corb and R. C. Desrosiers. 1992. AIDS vaccine developments. Nature (Lond.). 355:685-686.

42. Hu, S.-L., K. Abrams, G. N. Barber, P. Moran, J. Zarling, A. J. Langlois, L. Kuller, W. R. Morton, and R. E. Benveniste. 1992. Protection of Macaques against SIV infection by subunit vaccines of SIV envelope glycoprotein gp160. Science (Wash. DC). 255:456-459.

43. Berman, P. W., T. J. Gregory, L. Riddle, G. R. Nakamura, M. A. Champe, J. P. Porter, F. M. Wurm, R. D. Hershberg, E. K. Cobb, and J. W. Eichberg. 1990. Protection of chimpanzees from infection by HIV-1 after vaccination with recombinant glycoprotein gp120 but not gp 160. Nature (Lond.). 345:622-625.

44. Girard, M., M. P. Kieny, A. Pinter, F. Barre Sinoussi, P. Nara, H. Kolbe, K. Kusumi, A. Chaput, T. Reinhart, E. Muchmore et al. 1991. Immunization of chimpanzees confers protection against challenge with human immunodeficiency virus. Proc. Natl. Acad. Sci. USA. 88:542-546.

45. Fultz, P. N., P. Nara, F. Barre-Sinoussi, A. Chaput, M. L. Greenberg, E. Muchmore, M.-P. Kieny, and M. Girard. 1992. Vaccine protection of chimpanzees against challenge with HIV-1-infected peripheral blood mononuclear cells. Science (Wash. DC). 256:1687-1690.

46. Emini, E. A., W. A. Schleif, J. H. Nunberg, A. J. Conley, Y. Eda, S. Tokiyoshi, S. Putney, S. Matsushita, K. E. Cobb, C. M. Jett et al. 1992. Prevention of HIV-1 infection in chimpanzees by gp $120 \mathrm{~V} 3$ domain-specific monoclonal antibody. Nature (Lond.). 355:728-730.

47. Dolin, R., B. S. Graham, S. B. Greenberg, C. O. Tacket, R. B. Belshe, K. Midthun, M. L. Clements, G. J. Gorse, B. W. Horgan, R. L. Atmar et al. 1991. The safety and immunogenicity of a human immunodeficiency virus type 1 (HIV-1) recombinant gp160 candidate vaccine in humans. NIAID AIDS Vaccine Clinical Trials Network. Ann. Intern. Med. 114:119-127.

48. Redfield, R. R., D. L. Birx, N. Ketter, E. Tramont, V. Polonis, C. Davis, J. F. Brundage, G. Smith, S. Johnson, A. Fowler et al. 1991. A phase I evaluation of the safety and immunogenicity of vaccination with recombinant gp160 in patients with early human immunodeficiency virus infection. Military Medical Consortium for Applied Retroviral Research. N. Engl. J. Med. 324:1677-1684.

49. Syu, W. J., J. H. Huang, M. Essex, and T. H. Lee. 1990. The N-terminal region of the human immunodeficiency virus envelope glycoprotein gp 120 contains potential binding sites for CD4. Proc. Natl. Acad. Sci. USA. 87:3695-3699.

50. Lasky, L. A., G. M. Nakamura, D. H. Smith, C. Fennie, C. Shimasaki, E. Patzer, P. Berman, T. Gregory, and D. J. Capon. 1987. Delineation of a region of 
the human immunodeficiency virus type $1 \mathrm{gp} 120$ glycoprotein critical for interaction with the CD4 receptor. Cell. 50:975-985.

51. Shafferman, A., J. Lennox, H. Grosfeld, G. Sadoff, R. R. Redfield, and D. S. Burke. 1989. Patterns of antibody recognition of selected conserved amino acid sequences from the HIV envelope in sera from different stages of HIV infection. AIDS Res. Hum. Retroviruses. 5:33-39.

52. Gnann, J. W., P. L. Schimmbeck, J. A. Nelson, B. A. Truax, and M. B. A. Olston. 1987. Diagnosis of AIDS by using a 12-amino acid peptide representing an immunodominant epitope of human immunodeficiency virus. J. Infect. Dis. 156:261-267.

53. Dalgleish, A. G., T. C. Chanh, R. C. Kennedy, P. Kanda, P. R. Clapham, and R. A. Weiss. 1988. Neutralization of diverse HIV-1 strains by monoclonal antibodies raised against a gp41 synthetic peptide. Virology. 165:209-215.

54. Harada, S., Y. Koyanagi, and N. Yamamoto. 1985. Infection of HTLVIII/LAV in HTLV-I-carrying cells MT-2 and MT-4 and application in a plaque assay. Science (Wash. DC). 229:563-566.

55. Skinner, M. A., A. J. Langlois, C. B. McDanal, J. S. McDougal, D. P. Bolognesi, and T. J. Matthews. 1988. Neutralizing antibodies to an immunodominant epitope sequence do not prevent gp 120 binding to CD4. J. Virol. 62:41954200.

56. Lane, H. C., H. Masur, E. P. Gelmann, D. L. Longo, R. G. Steis, T. Chused, G. Whalen, L. C. Edgar, and A. S. Fauci. 1985. Correlation between immunologic function and clinical subpopulations of patients with the acquired immune deficiency syndrome. Am. J. Med. 78:417-422.

57. Benn, S., R. Rutledge, T. Folks, J. Gold, L. Baker, J. McCormick, P. Feorino, P. Piot, T. Quinn, and M. Martin. 1985. Genomic heterogeneity of AIDS retroviral isolates from North America and Zaire. Science (Wash. DC). 230:949-954.

58. Bolognesi, D. P. 1989. Prospects for prevention of and early intervention against HIV. JAMA (J. Am. Med. Assoc.). 261:3007-3013.

59. Martinez, A. C., M. A. R. Marcos, A. de la Hera, C. Marquez, J. M. Alonso, M. L. Toribio, and A. Coutinho. 1988. Immunological consequences of HIV infection: advantage of being low responder casts doubts on vaccine development. Lancet. 1:454-456.

60. Keefer, M. C., W. Bonnez, N. J. Roberts, R. Dolin, and R. C. Reichman. 1991. Human immunodeficiency virus (HIV-1) gp160-specific lymphocyte proliferative responses of mononuclear leukocytes from HIV-1 recombinant gp 160 vaccine recipients. J. Infect. Dis. 163:448-453.
61. Tacket, C. O., S. Baqar, C. Munoz, and J. R. Murphy. 1990. Lymphoproliferative responses to mitogens and HIV-1 envelope glycoprotein among volunteers vaccinated with recombinant gp160. AIDS Res. Hum. Retroviruses. 6:535542.

62. Clerici, M., C. O. Tacket, C. S. Via, D. R. Lucey, S. C. Muluk, R. A. Zajac, R. N. Boswell, J. A. Berzofsky, and G. M. Shearer. 1991. Immunization with subunit human immunodeficiency virus vaccine generates stronger $T$ helper cell immunity than natural infection. Eur. J. Immunol. 21:1345-1349.

63. Gorse, G. J., R. B. Belsche, F. K. Newman, and S. E. Frey. 1992. Lymphocyte proliferative responses following immunization with human immunodeficiency virus recombinant gp160. Vaccine. 10:383-388.

64. Orentas, R. J., J. E. Hildreth, E. Obah, M. Polydef kis, G. E. Smith, M. L. Clements, and R. F. Siliciano. 1990. Induction of CD4+ human cytolytic T cells specific for HIV-infected cells by a gp160 subunit vaccine. Science (Wash. DC). 248:1234-1237.

65. Siliciano, R. F., R. C. Bollinger; K. M. Callahan, S. A. Hammond, A. Y. Liu, E. P. Miskovsky, J. F. Rowell, and P. E. Stanhope. 1992. Clonal analysis of T-cell responses to the HIV-1 envelope proteins in AIDS vaccine recipients. AIDS Res. Hum. Retroviruses. 8:1349-1352.

66. Hammond, S. A., E. Obah, P. Stanhope, C. R. Monell, M. Strand, F. M. Robbins, W. B. Bias, R. W. Karr, S. Koenig, and R. F. Siliciano. 1991. Characterization of a conserved T cell epitope in HIV-1 gp4l recognized by vaccine-induced human cytolytic T cells. J. Immunol. 146:1470-1477.

67. Cooney, E. L., A. C. Collier, P. D. Greenberg, R. W. Coombs, J. Zarling D. E. Arditti, M. C. Hoffman, S. L. Hu, and L. Corey. 1991. Safety of and immunological response to a recombinant vaccinia virus vaccine expressing HIV envelope glycoprotein. Lancet. 337:567-572.

68. Wintsch, J., C. L. Chaignat, D. G. Braun, M. Jeannet, H. Stalder, S. Abrignani, D. Montagna, F. Clavijo, P. Moret, J. M. Dayer et al. 1991. Safety and immunogenicity of a genetically engineered human immunodeficiency virus vaccine. J. Infect. Dis. 163:219-225.

69. Zagury, D., J. Bernard, R. Cheynier, I. Desportes, R. Leonard, M. Fouchard, B. Reveil, D. Ittele, Z. Lurhuma, K. Mbayo et al. 1988. A group specific anamnestic immune reaction against HIV-1 induced by a candidate vaccine against AIDS. Nature (Lond.). 332:728-731.

70. Zagury, D., R. Leonard, M. Fouchard, B. Reveil, J. Bernard, D. Ittele, A. Cattan, L. Zirimwabagabo, M. Kalumbu, W. Justin et al. 1987. Immunization against AIDS in humans. Nature (Lond.). 326:249-250. 